\title{
SEARCHING FOR STARS: \\ WORK EXPERIENCE AS A JOB MARKET SIGNAL FOR WORKERS WITHOUT BACHELOR'S DEGREES
}

\author{
Peter Q. Blair \\ Tomas G. Castagnino \\ Erica L. Groshen \\ Papia Debroy \\ Byron Auguste \\ Shad Ahmed \\ Fernando Garcia Diaz \\ Cristian Bonavida \\ Working Paper 26844 \\ http://www.nber.org/papers/w26844 \\ NATIONAL BUREAU OF ECONOMIC RESEARCH \\ 1050 Massachusetts Avenue \\ Cambridge, MA 02138 \\ March 2020
}

We thank Jennifer Brodie, Sean Burke, Amy Mortimer, Martin Evelyn and Annemarie Korte for their valued partnership in this research. We would like to thank Bobby Chung, Nathan Hendren and members of the BE-Lab for helpful comments. The views expressed herein are those of the authors and do not necessarily reflect the views of the National Bureau of Economic Research. Further, the statements, findings, conclusions, views, and opinions contained and expressed here are not necessarily those of Accenture or any of its affiliated or subsidiary entities.

NBER working papers are circulated for discussion and comment purposes. They have not been peer-reviewed or been subject to the review by the NBER Board of Directors that accompanies official NBER publications.

(C) 2020 by Peter Q. Blair, Tomas G. Castagnino, Erica L. Groshen, Papia Debroy, Byron Auguste, Shad Ahmed, Fernando Garcia Diaz, and Cristian Bonavida. All rights reserved. Short sections of text, not to exceed two paragraphs, may be quoted without explicit permission provided that full credit, including $(\odot)$ notice, is given to the source. 
Searching for STARs: Work Experience as a Job Market Signal for Workers without Bachelor's Degrees

Peter Q. Blair, Tomas G. Castagnino, Erica L. Groshen, Papia Debroy, Byron Auguste, Shad Ahmed, Fernando Garcia Diaz, and Cristian Bonavida

NBER Working Paper No. 26844

March 2020

JEL No. E24,I24,J11,J24,O15

\begin{abstract}
The demand for a skilled workforce is increasing even faster than the supply of workers with college degrees - the result: rising wage inequality by education levels, and firms facing a skills gap. While it is often assumed that increasing the number of college graduates is required to fill this gap, this paper explores the extent to which workers without BA college degrees can help fill this gap. To find workers without BA degrees who are potentially skilled through alternative routes (STARs), we use data on the skill requirements of jobs to compute the "skill distance" between a worker's current occupation and higher wage occupations with similar skill requirements in their local labor market. Based on our calculations, of the 16 million non-college educated workers with skills for high-wage work (> twice median earnings), 11 million whom we term "Rising STARs" are currently employed in middle-to low-wage work. We propose a general taxonomy for STARs to identify potential job transitions to higher wage work within their current earnings category and across earnings categories.

Peter Q. Blair

Harvard University

Graduate School of Education

407 Gutman Library

Cambridge, MA 02138

and NBER

peter_blair@gse.harvard.edu

Tomas G. Castagnino

Accenture Research

tomas.g.castagnino@accenture.com

Erica L. Groshen

Former Commissioner of the

Bureau of Labor Statistics

Cornell University - ILR

erica.groshen@cornell.edu

Papia Debroy

Opportunity@Work

papia@opportunityatwork.org

Byron Auguste

Opportunity@Work

byron@opportunityatwork.org

Shad Ahmed

Opportunity@Work

shad@opportunityatwork.org

Fernando Garcia Diaz

Accenture Research

fernando.garcia.diaz@accenture.com

Cristian Bonavida

Accenture Research

cristian.foschiatti@accenture.com
\end{abstract}




\section{$\underline{\text { Introduction }}$}

Over the past several decades, the US economy has been characterized by the increasing number of workers obtaining college degrees and increasing returns to college (Katz and Murphy 1992; Autor, Goldin, and Katz 2020). Workers with less than a bachelor's degree, however, have experienced declining fortunes with the returns to sub-BA levels of education remaining stagnant for women and falling for men during the past 3 decades (Autor 2014). The rising college wage premium is explainable in part by skill-biased technological change increasing the relative returns to college educated workers (Tinbergen 1974). However, the concurrent decline of real wages of non-college educated workers runs counter to the maintained assumption that skilled and unskilled labor are complements, as Autor points out in his 2019 Ely Lecture at the American Economic Association (Autor 2019). Deepening this puzzle further, the disproportionate demand for collegeeducated workers in the US has not abated even after years of progressive labor market tightening following the great recession (Blair and Deming 2020).

A growing literature within economics seeks to explain aspects of this puzzle (Autor, Katz, and Kearney 2006; 2008; Goos and Manning 2007; Goos, Manning, and Salomons 2014; Autor, Goldin, and Katz 2020). In this paper we provide some descriptive facts that are consistent with the hypothesis that some of the college wage premium and the stagnant/declining fortunes of workers without college degrees may be due to ineffective signaling of the relevant skills (which many non-college graduates acquire through work experience) rather than to differential skill levels per se between workers with and without BA degrees. The goal of this paper is to describe facts about the skills of workers without BA degrees and to define a population of working adults without bachelor's degrees who have work experience and skills that could position them for transitions to higher wage jobs. These "STARs" (i.e., "Skilled Through Alternative Routes") make up almost 70 million workers in the US economy today. To do this, we construct a simple index of work experience similarity that illustrates the compatibility between current on-the-job experience by non-college educated workers and the experience requirements in higher wage jobs.

Because the skill content of a job is high dimensional, both firms and workers may have incomplete information about the similarity in skill content across occupations that are drawn from different industries and job groups. This incomplete information may be particularly acute for workers without traditional job market signals -- notably workers without BA degrees. Moreover, the problem of incomplete information may derive from rational inattention on both the demand side and the supply side (Laibson 1997; Sims 2003; Gabaix 2014; Matějka and McKay 2015; Caplin and Dean 2015). For example, a human resources recruiter or a hiring manager may find it optimal to specialize in searching for workers with a particular set of industry experiences because it is costly to cast a wider recruitment net. For the recruiter, casting a wider net requires investing time to learn how a seemingly unrelated industry may employ workers with skills that are relevant to working in the target industry. Moreover, casting a wider net in the absence of an additional labor market signal may reduce both the average quality of matches and the hit rate of matches.

On the supply-side, workers also face the cost of learning how the skills in their current job can map onto jobs in other seemingly unrelated fields; and likewise casting a wider job search net may also reduce both the average quality and hit rate of job offers for the job seeker. Rational inattention on both supply and demand-side may, moreover, prove to be a self-fulfilling prophecy (Coate and Loury 1993; Arrow 1986). Furthermore, the high degree to which firms rely on employee referrals compounds the potential for incomplete information to result in workers without college degrees earning lower wages than are possible and firms missing out on a 
potentially well-suited group of workers who lack traditional job market signals like college degrees (Pallais 2014; Pallais and Sands 2016). Our work is motivated by the idea that signals can help workers to get a foot in the door even if their value diminishes over time as the firm learns more about the workers productivity. We posit that the skill content of a worker's current job is a high dimension piece of information that can function as a job market signal, particularly for noncollege educated worker's (Spence 1973, Altonji and Pierret 2001). Specifically, we posit that the skill content of a worker's current job provides high-dimensional information that can function as a job market signal, particularly for non-college educated workers.

Using the O*NET data, we construct a skill vector for every occupation based on the 35 skills measured there. For each occupation, this vector consists of a skill intensity measure ranging from 1-5 for each skill. To measure how closely related two occupations are, we compute the Euclidean distance between the skill vectors of the two occupations. An attractive feature of using distance is the usefulness of physical and notional distances in other economic contexts, e.g. iceberg distance as a key explanatory variable for the patterns of international trade, and distance in attribute space between competing products as an instrumental variable for prices in discrete choice models (Donaldson 2018, Bergstrand 1985, Gandhi Houde 2020). Looking at the relatedness of occupations with a Euclidean "skill distance" measure is also a tractable way to reduce the dimensionality of the skill vector from a 35 dimensional vector to a 1 dimensional scalar that is portable across contexts.

For example, the skill distance between the Brickmasons, Blockmasons, and Stonemasons occupation and Welding, Soldering and Brazing occupation is in the 25th percentile of all skill distances in our sample, indicating a high degree similarity in the skills required for the two roles. These roles, however, differ in hourly wages: the first role is low-wage, and the second is middlewage. Whereas the first role pays an average of $\$ 13.71$ in Florida, the second role pays an average of $\$ 23.91$ in the same state. It could be incidental that the two roles are in different job families, i.e. the 2-digit SOC code indicates the first occupation is in the Construction job family whereas the second occupation is in the Production job family. Alternatively, this difference in job group categorization, skill similarity notwithstanding, could be central to understanding the wage differences across jobs and indicate opportunities to improve allocative efficiency in the labor market in the presence of an additional job market signal.

The fact that many jobs in different industries share common skills but differ substantially in mean wages suggests that there may be incomplete information in the labor market and potential pathways for non-BA workers to become skilled through alternative routes (STARs). In defining STARs we are thinking about individuals whose skill profile based on current work is proximate to the skill profile of a higher paying occupation. Using this STARs framework, we create a taxonomy of non-college educated workers that provides a shared lexicon for researchers, firms, workers and policy makers to describe these workers. This taxonomy is based on their potential earnings given the skills required in their current occupation and that occupation's proximity to higher wage occupations. We show that STARs are in all 23 major job groups defined by the O*NET; those earning high-wages are clustered in Computer and Mathematics as well as Management roles. Those earning low-wages are distributed across jobs including the lowest wage jobs in Personal and Care, Food Preparation. Each STAR has the skills to transition to a higher paying role based on the skill distance between their original and destination jobs and the fact that other works are recorded in the data to have made the same job transition in the past. 

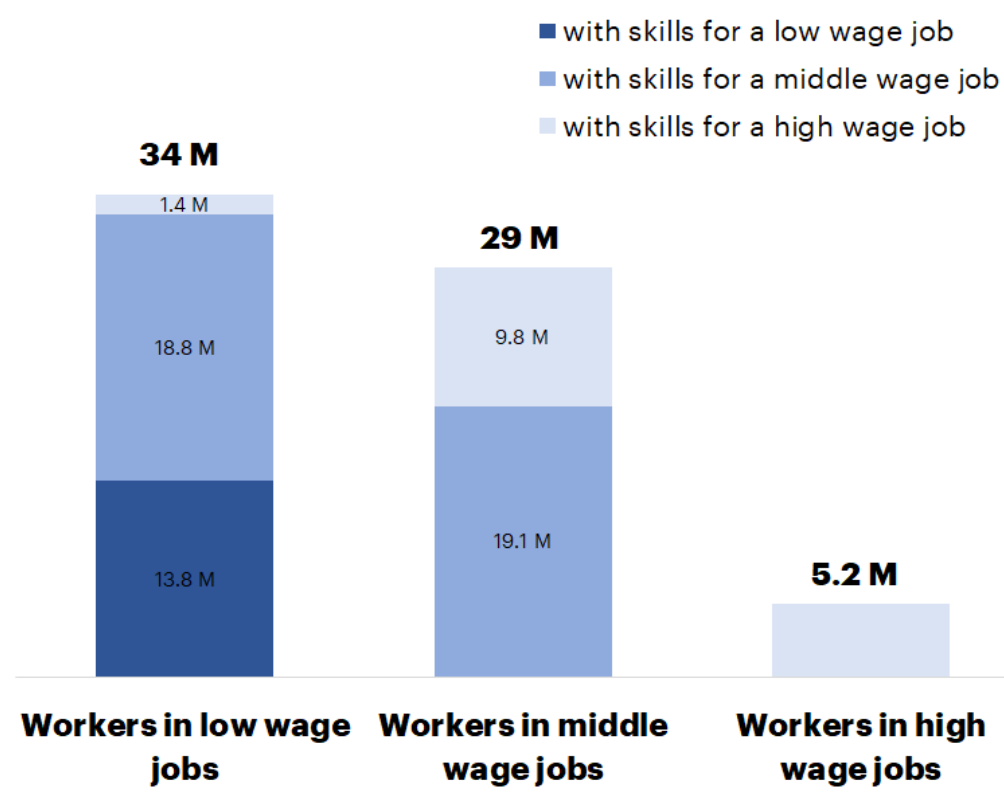

Figure 1: Non-college educated workers by wage group and skill similarity to workers in higher wage groups - In Millions

Note: It excludes workers without a high school degree. See 'Data and Methods' section for wage ranges and skill similarity definitions.

Dividing the earnings distribution into three groups, we define (1) "Shining Stars" as noncollege educated workers already earning $>$ twice the median wages in state-cohort earnings distribution, (2) "Rising Stars" as non-college educated workers with skills to transition into middle to high-wage occupations where average earnings exceed the median wages in their statecohort earnings distribution, and (3) "Forming Stars" as non-college educated workers with skills to transition into higher wage occupations with in their current earnings category. As shown in Figure 1, of the total non-college educated workers active in the in the US labor force $5 \%$ fit our categorization of Shining Stars, 30\% "Rising STARs" and 33\% are "Forming STARS." There is significant and meaningful variation across this pool of workers. STARs in high-wage roles today are disproportionately white men, whereas STARs in low-wage roles with few transition opportunities see a disproportionate volume of underrepresented groups of women.

Indeed, there are a host of other attributes of the jobs that are unobserved to the econometrician which may also explain differences in wages. Many of these we will not be able to account for with the skill distance. With this caveat in mind, we view what we do in this paper as a descriptive exercise that lays the foundation for our forthcoming work which hones in on causal mechanisms. Nevertheless, and perhaps just as important, our findings are of immediate relevance and utility to workers, employers, and the workforce development community. We offer a way to systematically identify which jobs are close in the "skill space" to each other but are far apart in terms of earnings potential. Sub-setting the data into a sample of workers who are STARs if done with enough granularity and if sufficiently informative has the potential to generate a separating equilibrium among non-BA workers that enables both the firms and workers to identify potentially fruitful job matches. Moreover, surmounting the separation would only require knowing and managing the skill distance between the origin and destination jobs. Thus, there is no need for additional (costly) investment in education on the part of workers without college 
degrees to signal skills. In short, providing this information could make the job market (weakly) more efficient, to the extent that firms and workers are rationally inattentive.

\section{Impetus for Focus on Workers Without College Degrees}

If the signaling failure described above is pervasive, it could well underlie the three dominant trends in the labor market today, which are stagnant median real wages, rising inequality, and declining labor force participation. These overall trends are most pronounced for non-college workers. Indeed, as a corollary, these poor outcomes may continue to worsen absent efforts to address this particular market failure facing non-college workers.

As noted above, the majority of US workers do not hold a 4-year college degree $(62 \%$ of workers age 25 and older in 2016-2017). ${ }^{1}$ Starting with wages, Figure 2 shows real wage levels and growth by educational attainment from 1979 to 2016. For college graduates, real median wages have increased, whereas for non-BA workers, they have fallen substantially. Thus, overall stagnant median real wages are largely driven by the experience of non-college workers. And, since wages for college-educated workers have increased, stagnant wages for non-college workers contributes substantially to rising wage inequality in the US.

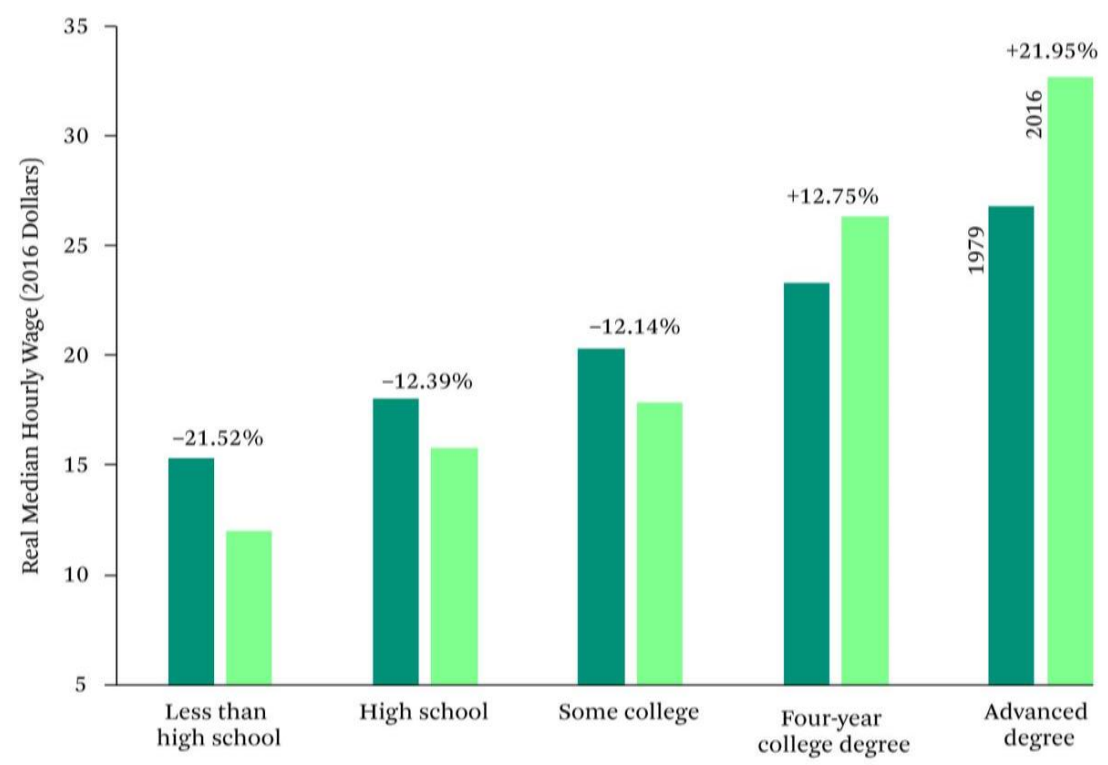

Source: Authors' calculations based on Current Population Survey data (U.S. Census Bureau 19792016).

Note: Wages are median hourly earnings and deflated using the CPI-U-RS. Sample includes those age twenty-five to fifty-four.

\section{Figure 2. Real Wage Levels and Growth by Educational Attainment}

Source: Reproduced from Groshen, Erica L. and Harry J. Holzer (2019a). "Improving Employment and Earnings in Twenty-First Century Labor Markets: An Introduction," RSF: The Russell Sage Foundation Journal of the Social Sciences December 2019, 5 (5) 1-19; DOI: https://doi.org/10.7758/RSF.2019.5.5.0

\footnotetext{
${ }^{1}$ Bureau of Labor Statistics, U.S. Department of Labor, Employment Projections, Table 5.3 "Educational attainment for workers 25 years and older by detailed occupation, 2016-2017." https://data.bls.gov/projections/occupationProj.
} 
In addition, males without college degrees have seen their labor force participation decline dramatically, much more than the decline for those with BA degrees, as shown in Figure 3. It is no unfathomable to think that earnings stagnation and declining participation could be related. That is, poor earnings prospects could reduce the propensity of non-BA men to enter or stay in the labor force.

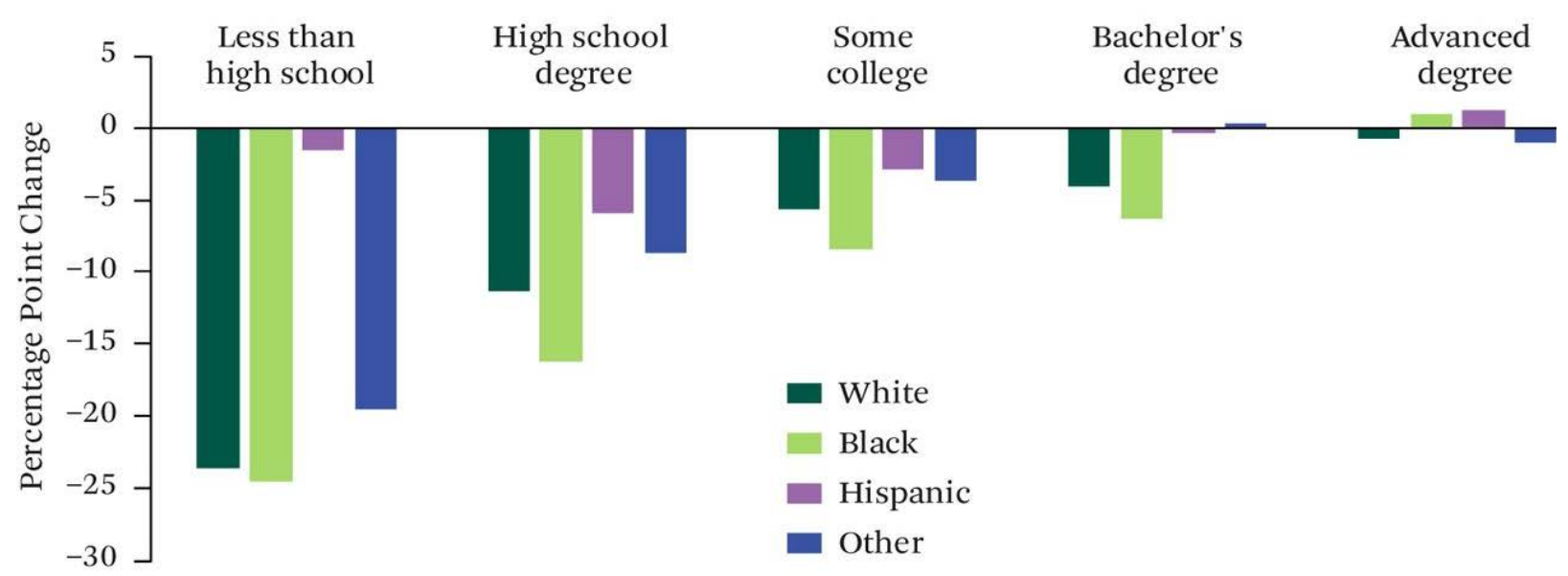

Source: Authors' calculations based on Current Population Survey data (U.S. Census Bureau 19792016).

Note: Sample includes men age twenty-five to fifty-four.

Figure 3. Labor-Force Participation Changes, Prime-Age Men by Education

Source: Reproduced from Groshen, Erica L. and Harry J. Holzer (2019a). "Improving Employment and Earnings in Twenty-First Century Labor Markets: An Introduction," RSF: The Russell Sage Foundation Journal of the Social Sciences December 2019, 5 (5) 1-19; DOI: https://doi.org/10.7758/RSF.2019.5.5.01

In a recent Russell Sage Foundation volume, 24 prominent researchers examine the three long-run trends from many angles and agree that the forces behind these poor outcomes are unlikely to abate in the coming decades. ${ }^{2}$ The multiplicity of causes of the trends suggest that no single "silver bullet" policy is likely to be able to reverse these trends alone. Moreover, the nature of the problem suggests that a key focus of research targeting these issues will center on job opportunities for non-BA workers.

Going forward, what do overall supply and demand conditions look like for non-BA workers? The pattern of occupational job creation during the most recent decade reinforces concern. It bodes poorly for workers without a 4-year college degree in the future-and for the many employers hoping to staff many positions with college graduates. Figure 4 compares four key numbers: supply and demand measures of stocks and flows by BA attainment or not. The top bar shows the stock of demand for BA workers, that is, the share of jobs that typically require a 4year college degree for entry-level positions (26\%). Just below is the supply of workers for those

${ }^{2}$ Groshen, Erica L. and Harry J. Holzer (2019b), eds. "Improving Employment and Earnings in Twenty-First Century Labor Markets," RSF: The Russell Sage Foundation Journal of the

Social Sciences, December 2019, 5(5); DOI: https://www.rsfjournal.org/content/5/5. 
jobs: the share of the workforce with a BA or more, which is $38 \%$. Interestingly, measured this way, the supply (38\%) is greater than the demand at the moment $(26 \%)$ - shown in the top bar. This difference suggests that at least $8 \%$ of workers are college degree holders with jobs in occupations that typically do not require a college degree for entry. Indeed, the true percentage of "underemployed" college graduates is certainly higher because the unemployed are less likely to hold a college degree and (as we show below) some college jobs are held by STARs. The reasons college graduates hold non-college jobs include preferences, a local scarcity of appropriate college jobs, family or physical constraints, and occupations where college education is not strictly required but may increase success. ${ }^{3}$

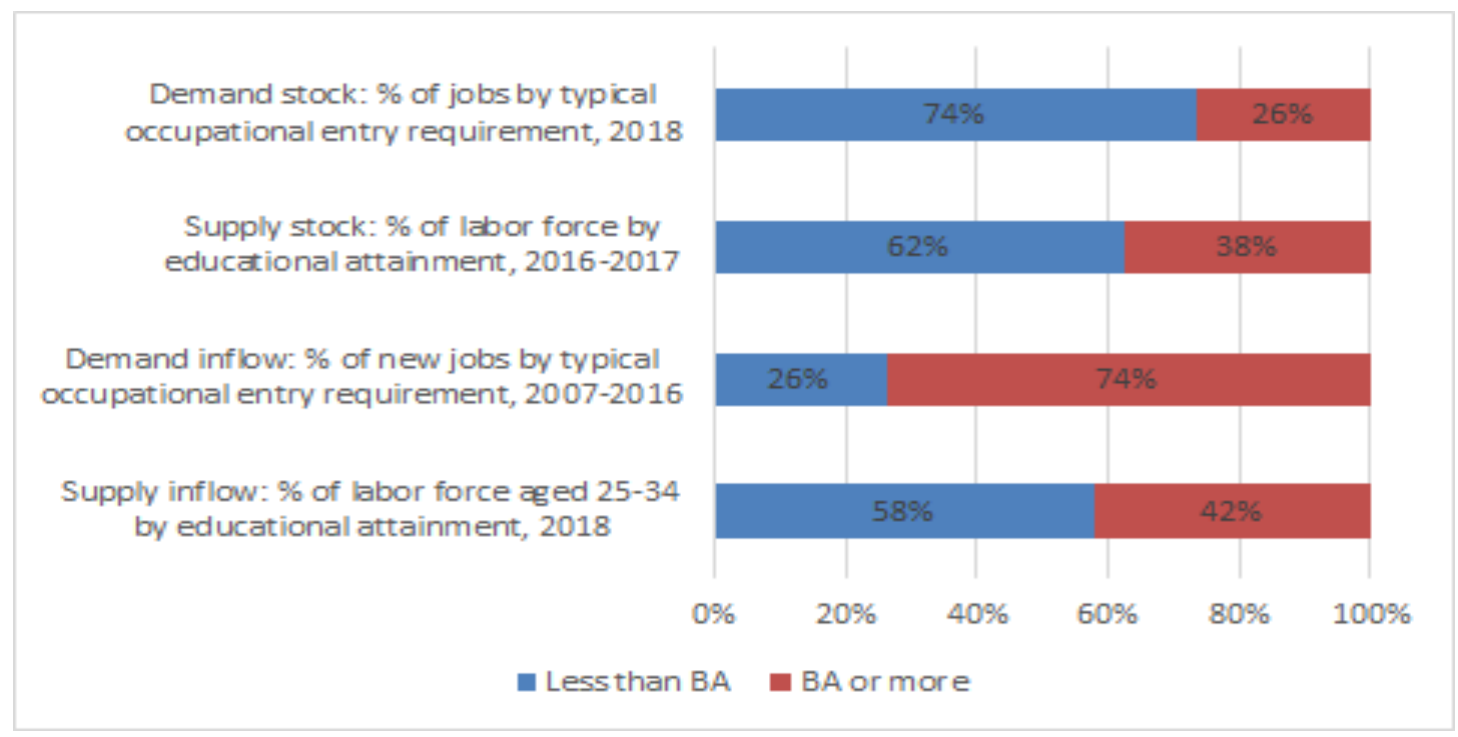

Figure 4. Supply of college-educated workers compared to requirements for jobs, recent stocks and inflows ${ }^{4}$

Note: The typical entry-level education requirements assigned to each occupation are based on research by the BLS Employment Projections program and may differ from the educational level of workers in the occupation and from the education that particular employers require for individual jobs in the occupation.

\footnotetext{
${ }^{3}$ Examples of occupations where a degree is not required but may improve success include elected officials, computer programmers, artists, and sales jobs aimed at sophisticated clienteles.

${ }^{4}$ Share of jobs by typical occupational entry requirement: Bureau of Labor Statistics, U.S. Department of Labor, Employment Projections, Table 1.7 Occupational projections, 2018-28, and worker characteristics, 2018.

https://data.bls.gov/projections/occupationProj (visited February 21, 2020); Share of labor force by educational attainment, 2016-2017: Bureau of Labor Statistics, U.S. Department of Labor, Employment Projections, Table 5.3 Educational attainment for workers 25 years and older by detailed occupation, 2016-17, https://data.bls.gov/projections/occupationProj (visited February 21, 2020); Share of new jobs by typical occupational entry requirement, 2018-2028: Bureau of Labor Statistics, U.S. Department of Labor, The Economics Daily, Occupations typically requiring high school for entry lost 1.3 million jobs, May 2007-16 on the Internet at https://www.bls.gov/opub/ted/2017/occupations-typically-requiring-high-school-for-entry-lost-1-3-million-jobsmay-2007-16.htm (visited February 21, 2020); Share of labor force aged 25-34 by educational attainment, 2018: U.S. Census Bureau, Current Population Survey, Annual Social and Economic Supplement, 2018. https://www.census.gov/cps/data/cpstablecreator.html (visited February 28, 2020)
} 
Most strikingly for this study is the reversed and much larger gap between the inflows of demand and supply for college-educated workers, shown in the lower two bars of figure 4 . The Bureau of Labor Statistics reports that from 2007 to 2016, 74\% of new jobs were in occupations where employers that typically require a 4-year college degree, double the share in ongoing jobs. Compared to the stocks above, we see clear evidence that employers' need for workers in skilled occupations expanded strongly in the last decade. Filtered through their common hiring practices, this need for upskilling dramatically shifted the educational requirements for new jobs. Consider the implications of a persistence of this hiring trend into the next decade. If it continues as is, only $26 \%$ of new jobs will be available to the $58-62 \%$ of US workers without a college degree. Turning the same numbers around for the employer perspective, only $38-42 \%$ of workers will be eligible for 74 percent of new jobs. Simply put, these trends portend serious challenges for employers in the near term, along with worse outcomes for workers with low levels of formal education. ${ }^{5}$

Can we catch up by increasing college attendance? It is unlikely that improving college attendance alone in the near term will close the skills gap for employers or reverse the deterioration in the labor market outcomes of less educated workers. The bottom bar of Figure 3 shows that in $2018,42 \%$ of 25-34 year-olds in the workforce had a BA or more. Focusing on the youngest cohort in the labor force is a way to gauge the rate of inflow of college-educated workers. This increment of about four percentage points higher than the college share of the workforce as a whole is not enough higher to move the needle quickly. Nor does the inflow come close to matching what new jobs look like--taking the $74 \%$ rate of college requirements in new jobs during the last decade as indicative. Over the past 27 years (1992 to 2019), the U.S. has raised the share of U.S. workers with 4-year college degrees by only 15 percentage points--an average pace of 0.56 percentage points per year. Even if policies to raise graduations were adopted now (via, say, dramatic increases in funding for public colleges) it would take many years for colleges to dramatically increase the inflow of college graduates into the labor market.

The difficulty of creating enough quality seats in college bachelor's degree programs to keep pace with projections of the U.S. labor market's 'degree requirements' requires a deeper look at workers without BA degrees as potential pool of skilled workers. The descriptive facts that we share in this paper suggests significant potential for STARs to successfully fill higher paid, indemand job roles for which their experienced-based skills have prepared them. But what about new jobs roles - technology enabled with higher-than-average wages - ushered in by a range of new technologies and business methods? While some of these new occupations (e.g., data scientist) may require skills (e.g., statistical methods) which are typically acquired in advanced formal education, a large number (e.g., application developers and administrators for enterprise Software-as-a-Service platforms such as Salesforce, Workday, or ServiceNow) are learned not in formal education, but mostly on-the-job or in credentialed skill training designed by the SaaS companies themselves. While estimating STARs' potential to fill skilled roles still emerging is beyond the scope of this paper, it would be reasonable to expect that employers' rational ignorance or deprecation of experienced-based signals of STARs skills for existing jobs may similarly shape

\footnotetext{
${ }^{5}$ Note that BLS employment projections for 2018-2028 suggest a weaker bias toward jobs that require a college degree during the next decade than seen during the last decade. They project that $42 \%$ of new jobs will require a BA. Even that conservative rate implies that occupations requiring a college degree will grow by $8.2 \%$--double the $4.1 \%$ growth expected for jobs typically requiring less than a college degree. The BLS projection model is bound by both demographic projections for educational attainment of the labor force and the assumption of fixed occupational education attainment requirements. This paper presents evidence that, in practice, relaxing many current occupational education requirements for a college degree may be another, preferable way to match demand with supply over the coming decade. https://www.bls.gov/emp/tables/education-summary.htm
} 
employer beliefs/preferences about the academic requirements for many new jobs. Thus, over the next decade, in addition to whatever needed changes we make to access to higher education, improving the efficacy with which existing cadres of experienced workers with strong labor market attachment but without college degrees can signal their skills for in-demand jobs in both existing and emerging occupational fields will be essential to reduce the likelihood of labor market imbalances and to improve labor market outcomes for millions of Americans.

\section{$\underline{\text { Data and Methods }}$}

The analysis is based on two main databases - O*NET of the U.S. Department of Labor and the Current Population Survey (CPS) of the Bureau of Labor Statistics. We use the O*NET database to compute our experience similarity measure. $\mathrm{O}^{*} \mathrm{NET}$ is one of the most comprehensive public data source for occupational information. It provides a periodically updated and standardized Content Model for 974 individual occupations categorized by a standard occupation code (SOC), assessing topics such as required education, abilities, experience, tasks and skills. O*NET database is maintained and updated regularly through its Data Collection Program, which conducts a survey to sampled workers, occupational experts. ${ }^{6}$ Most of the information is collected from those surveys, while occupational analysts provide the importance and level information regarding the abilities and skills pertaining to each occupation. ${ }^{7}$

In this paper we use occupational skill requirements, taking them as a proxy for the skill possessed by each worker. The reason why we chose skills is because the O*NET Content Model considers them "work-related attributes acquired and/or developed through experience and education", which is precisely what we want to proxy, whereas abilities, for example, relate to "enduring attributes of the individual that influence the work performance." 8 ONET skill requirements measure the importance of 35 basic and cross-functional skills, in areas such as Content, Process, Social, Complex Problem Solving, Technical, System and Resource Management skills. Skill importance levels span from a minimum of 1 to a maximum of 5. To the extent that a worker wages capture the marginal product of labor, in a standard model of human capital high level of skills translate into wages.

We use the CPS to sample the worker population. The CPS is a monthly household survey providing one of the most important sources for labor force economic and social statistics. It is conducted by the US Census Bureau for the Bureau of Labor Statistics (BLS). From the 2018 Annual Social and Economic Supplement (ASEC) of the CPS we pull in data about the demographic information on individuals: earnings, race, gender, age, state of residence etc. ${ }^{9} \mathrm{We}$

\footnotetext{
${ }^{6}$ Questionnaires are available online at the O*NET Data Collection Site: https://onet.rti.org/pdf/index.cfm.

${ }^{7}$ Previous version of the database collected both skills and abilities importance from job incumbents, but recent research suggests that trained occupational analysts understand the skill constructs better than incumbents. Detailed methodology available at: https://www.onetcenter.org/dl_files/AOSkills_ProcUpdate.pdf

${ }^{8}$ Other elements of the Content Model might also prove useful in future research. For example, the Generalized Work Activities, which outline the activities performed in each role. We preferred using skills in the analysis that we describe below, since we want to understand transition possibilities between occupations. So even if the involved activities may prove to be different in each occupation, the required skills to perform them might be similar anyway. Thus, a worker possessing those skills may be able to move from one role to the other, even when the implied activities will differ.

9 The Annual Social and Economic (ASEC) Supplement provides the usual monthly labor force data, but in addition, provides supplemental data on work experience, income, noncash benefits, and migration. We prefer the ASEC over the monthly CPS data for demographics as it provides better income coverage. We used the 2018 CPS-
} 
also exploit the panel structure of the CPS to measure job transitions across occupations within the overall active population of workers in the U.S.. When we construct our experience similarity measure between occupations, we will use the existence of actual job-to-job transitions in the data as a proof-of-concept that the pathways to higher wage jobs for STARs that we describe are plausible. $^{10}$

For each worker in the CPS under the declared occupation we match the O*NET skill requirements for that same occupation to the worker. Note that the matching was done between CPS OCC Code and O*NET SOC code using the official crosswalk provided by IPUMS-CPS. O*NET provides skills for occupations at an 8-digit depth, while the CPS OCC Codes are equivalent in depth to 6-digit SOC Codes, so we first take the 6-digit skill averages from the O*NET Skill database. We then match those averages with the CPS Codes. Most of the occupations match at the 6-digit level (65\%), but we leveraged 5-digit (23\%) and 4-digit (12\%) averages for the ones that didn't match at the 6-digit level.

\begin{tabular}{|c|c|c|}
\hline Skill Group & Skill Group Description & Skill \\
\hline \multirow{6}{*}{ Content } & \multirow{6}{*}{$\begin{array}{l}\text { Background structures needed to work with and acquire more specific } \\
\text { skills in a variety of different domains }\end{array}$} & Reading Comprehension \\
\hline & & Active Listening \\
\hline & & Writing \\
\hline & & Speaking \\
\hline & & Mathematics \\
\hline & & Science \\
\hline \multirow{4}{*}{ Process } & \multirow{4}{*}{$\begin{array}{l}\text { Procedures that contribute to the more rapid acquisition of knowledge } \\
\text { and skill across a variety of domains }\end{array}$} & Critical Thinking \\
\hline & & Active Learning \\
\hline & & Learning Strategies \\
\hline & & Monitoring \\
\hline \multirow{6}{*}{ Social Skills } & \multirow{6}{*}{ Developed capacities used to work with people to achieve goals } & Social Perceptiveness \\
\hline & & Coordination \\
\hline & & Persuasion \\
\hline & & Negotiation \\
\hline & & Instructing \\
\hline & & Service Orientation \\
\hline
\end{tabular}

Table 1. Sample of $O * N E T$ skill requirements

\footnotetext{
ASEC for demographics as this was the latest edition at the moment of writing, but tested the main aggregates against the 2019 monthly data finding no relevant differences.

${ }^{10}$ As explained later, to explore the job-to-job transitions we used not only the latest available CPS-ASEC (2018) but the latest 4 at the moment of writing (2015-2018) in order to improve the amount of sampled transitions. Other sources for demographic data also exist, the American Community Survey (ACS) being one of the most common in similar studies. We cross checked some of our intermediate results with the ACS, such as the earnings by occupation, educational attainment shares, population distribution between MSAs and States, arriving at similar values. The ACS has a better geographical coverage, providing a bigger sample, but has a lower sampling frequency (1, 3 or 5 years) and does not provide information about occupational transitions, which was critical information for our study.
} 
Based on the skills of the current occupation, we calculate the Euclidean distance $d_{i, j}$ between the skill vector of the of a worker's current occupation $s_{i}=\left(s_{i, l}, \ldots, s_{i, k} \ldots, s_{i, 35}\right)$ (the origin occupation) and a potential destination occupation, $s_{j}=\left(s_{j, 1}, \ldots, s_{j, k} \ldots, s_{j, 35}\right)$, as follows:

$$
d_{i, j}=\sqrt{\sum_{k=1}^{k=35}\left(s_{i, k}-s_{j, k}\right)^{2}}
$$

We considered other measures that are also used in the literature, most prominently the cosine similarity -- often used for text analysis -- but because the Euclidean distance allowed us to consider absolute magnitudes, while the cosine similarity weighs the relative importance of each element of the vector, we chose to deploy this method. ${ }^{11}$ Furthermore, one could also considered a weighted analog of our distance measure where the weights are determined by factors external to the $\mathrm{O}^{*}$ Net database. These alternative measures are likely to be highly correlated and the reader can think about our proposed measure as just one way of capturing the skill distance between occupations.

We focus our analysis on individuals who are active in the labor market and above the age of 25 with a high school diploma ${ }^{12}$ or equivalent and without a bachelor's degree. We excluded workers who are not currently employed or did not have occupational data available in the Current Population Survey (CPS), since we cannot compute a skill distance measure based on current employment. These sample restrictions focus our study on a population of 68 million workers, ${ }^{13}$ which we call our Target Study Population (TSP). ${ }^{14}$ By comparison there are 60 million individuals who are active in the labor market in the same age range who possess a BA degree or higher.

With our TSP defined, we split the population into three groups using a grouping based on median hourly wages, which were localized based on state, age and occupation. ${ }^{15}$ Specifically, we use the state level median wage to define the income thresholds: low, middle, and high. We calculate the median wages for each occupation, considering both state and age range (25-34, 3544, 45-54, 55-64, 65+) using the following definitions:

i. Low-wage: those in an occupation with median hourly wage (for that state and age cohort) below than the state median wage. As a reference, the national median is near $\$ 38,000 /$ year, with a substantial degree of state-level variation (e.g. Mississippi $\$ 32,000 /$ year, Colorado $\$ 42,000 /$ year).

ii. Middle-wage: those in an occupation with median hourly wage above the state median wage and below than two times that measure. On average, this includes all occupations

\footnotetext{
${ }^{11}$ For literature covering similarity and proximity measures readers can be referred to "Data Mining: Concepts and Techniques" (Han, Kamber, Pei, 2011) for an introductory treatment.

${ }^{12}$ Future analyses must be done to understand the skills of the population of workers without a high school diploma.

${ }^{13}$ These figures correspond to the expanded CPS according to the reported weights on each individual in the sample.

${ }^{14}$ We do not have occupational data about Opportunity Youth, but given the significant investment in ensuring this population acquires skills for meaningful career pathways, we included them in our STARs population estimate.

${ }^{15} \mathrm{We}$ also explored the possibility of using MIT Living Wages to build the three income groups, which could also provide a reasonable threshold for living standards across different US regions. We favored using hourly wage medians since they are more often used in labor economics literature, convey similar information, and allowed us to keep the analysis simple, without the need to refer to additional methodologies.
} 
where the worker earns between $\$ 38,000$ and $\$ 77,000$. We use two times the median wage as a simple cut point between middle and high incomes. ${ }^{16}$

iii. High-wage: those in an occupation with median hourly wage above than two times the state median wage. On average, this includes workers in occupations that earn above $\$ 77,000 /$ year threshold.

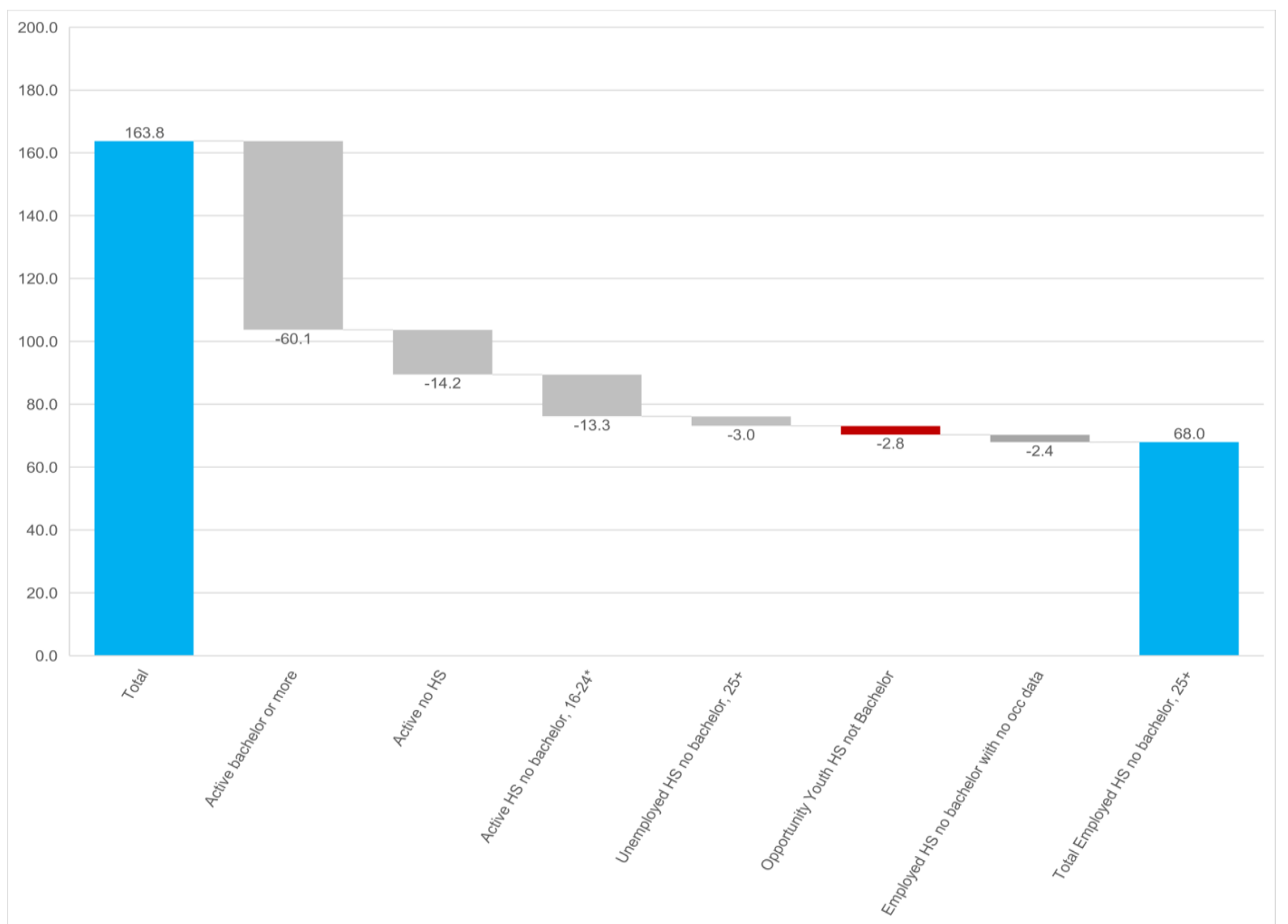

Figure 5. - Target Study Population (in millions)

Finally, we compare the occupation median wage (by state and age range) with the state median wage, to assign the workers to their relevant state-wage-cohort group and to characterize potential destination jobs. We use median wages instead of mean wages to reduce the prospect of outliers driving our wage definitions. Secondly, we use state level medians instead of the national ones to account for possible regional variation in wages and cost of living. ${ }^{17}$ Thirdly, when estimating the median wages we compute the medians separately by age cohort to reflect the fact that wages change over the life-cycle as work experience increases.

\footnotetext{
${ }^{16}$ At a national level, wages above two times the median represent approximately the highest $20 \%$. Pew Research Center uses a similar upper limit to define the American "middle class". Specifically, they define "middle-income" Americans are adults whose annual household income is two-thirds to double the national median, after incomes have been adjusted for household size.

${ }^{17}$ Metropolitan statistical area (MSA) level could also have been used towards that end, but the CPS data does not have enough granularity to allow for both MSA and occupation level estimates.
} 
In Table 2, we share the summary statistics and describe the characteristics of our TSP across the three wage groups. Our measure of skill distance is also increasing in the wage categories which suggest that high-wage jobs are further away in the skill space from other jobs. As we will see in the results section, this is linked to more opportunities to transition open to workers in occupations in low-wage groups relative to workers in high-wage occupations. Finally, workers in the low-wage group have a higher share of minorities relative to the middle and highwage groups.

\begin{tabular}{|c|c|c|c|c|c|}
\hline & Income Categories & Low wage & Mid wage & High wage & All \\
\hline Employment & Number & 33.9 Millions & 28.9 Millions & 5.2 Millions & 68.0 Millions \\
\hline \multirow{2}{*}{ Hourly wage } & Median & 14.31 & 23.81 & 43.21 & 20.55 \\
\hline & Standard deviation & 3.07 & 5.47 & 20.35 & 5.41 \\
\hline \multirow{2}{*}{ Age } & Mean & 43.51 & 46.93 & 50.80 & 45.52 \\
\hline & Standard deviation & 15.64 & 12.85 & 12.32 & 14.2 \\
\hline \multirow{2}{*}{$\begin{array}{l}\text { Years of formal } \\
\text { education }\end{array}$} & Mean & 12.62 & 12.81 & 13.00 & 12.73 \\
\hline & Standard deviation & 5.95 & 6.43 & 5.72 & 6.1 \\
\hline \multirow{5}{*}{ Race } & White & $73.9 \%$ & $81.8 \%$ & $85.8 \%$ & $78.2 \%$ \\
\hline & Black & $17.4 \%$ & $11.9 \%$ & $8.1 \%$ & $14.4 \%$ \\
\hline & American Indian & $1.3 \%$ & $1.0 \%$ & $0.5 \%$ & $1.1 \%$ \\
\hline & Asian & $4.8 \%$ & $3.3 \%$ & $3.6 \%$ & $4.1 \%$ \\
\hline & Other & $2.5 \%$ & $2.0 \%$ & $1.9 \%$ & $2.3 \%$ \\
\hline Skill Distance & Euclidian Distance & 1.66 & 2.25 & 2.43 & 1.97 \\
\hline
\end{tabular}

Table 2. Summary Statistics

Our first step in identifying a destination occupation for STARs is to compute the skill distance between a worker's current occupation and all other occupations. Next, we define several rules to determine if a destination occupation is a plausible job transition. The procedure is to look for the closest occupation in the skill distance that meets each of these transition rules. Overall, this approach is meant to impose more demanding criteria to potential transitions that may otherwise appear to be feasible if just skill distance were considered. For example, low-wage occupation 'Automotive Body and Related Repairers' [OCC code: 7150], based solely on skill similarity, would have as the second highest option the mid wage occupation 'Telecommunications Line Installers and Repairers' [OCC code: 7420]. However, after the filters are applied this option disappears and the first option becomes another mid wage occupation 'Molders and Molding Machine Setters, Operators, and Tenders, Metal and Plastic [OCC code: 7150]' which was previously ranked as the 11 th in terms of skill similarity.

To describe potential pathways to higher wage destination jobs, we look for destination jobs that: 1) are close in the skill space to the origin job, 2) currently employ some workers without BA degrees, 3) in the recent past have welcomed workers from the origin job who did not possess a BA degree and 4) pay higher average state-cohort median wages than the origin job. We implement these refinements using the following rules: 
i. Wage increase: For each possible origin-destination transition with higher average wages, we labelled whether the transition would represent a transition across wage categories, i.e. from low-wage to middle-wage/high-wage, or from middle-wage to highwage, or if the transition would represent a wage increase within wage category. category, we search for destination occupations with higher wages within the same category. The distinction between transitions that could increase wages on the extensive margin versus transitions that could increase wages on the intensive margin will figure prominently in our taxonomy of STARs.

ii. Barriers to entry: Not all individuals in the destination occupation should have a college degree. This was to rule out transitions into jobs where professional degrees are required or the norm (e.g. doctors). We used a $90 \%$ threshold, which means that at least $10 \%$ of people currently employed in that occupation do not have a college degree. We use the CPS microdata to build the college degree shares. The results were similar when we used the degree requirements reported in $\mathrm{O} * \mathrm{NET}$.

iii. Plausibility check: Is there evidence that this job-to-job transition has occurred before in the labor market? To assess the plausibility of origin-destination transitions, we compared current and last year occupations for each individual, as declared in the CPS's Annual Social and Economic Supplement (ASEC) during the last 4 years. We use a 4year period to account for the fact that some job-to-job transitions are rare and are less likely to be observed in single year-to-year transitions. We then ruled out origindestination pair with no observed transitions during this 4-year period.

iv. Skill gap: We limited our consideration set to destination occupations where the skill distance from the origin occupation is less than 2.5 . In practice, $70 \%$ of all year-to-year CPS job-to-job transitions meet this bar (see Figure 6). Moreover, this threshold is roughly one standard deviation above the average origin-destination distance weighted by the share of transitions occurring at that level.

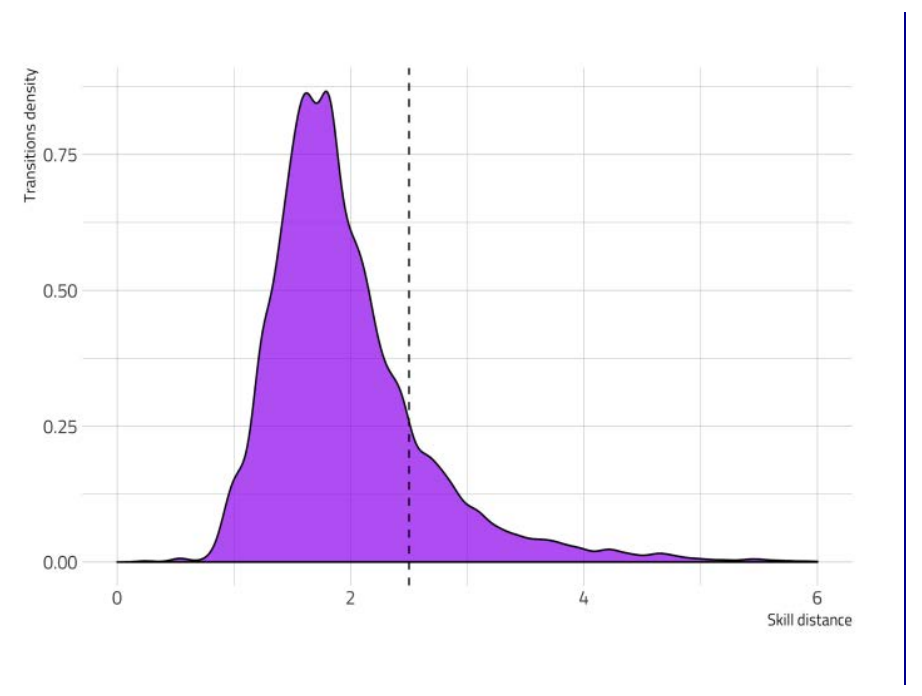

Figure 6. Transition density by Skill Distance 
The results in Table 3 are illustrative of transitions we predict. Here, we present data about two occupations in two different states, a Statistical Assistant, and a Childcare worker. The Statistical Assistant is responsible for compiling and computing data according to statistical formulas for use in statistical studies, according to the BLS description of the occupation, and include actuarial clerks. The skills this individual needs include mathematics, critical thinking and complex problem solving, among other skills. Statistical assistants are paid an average wage of $\$ 17.61 / \mathrm{hr}$ in California, and approximately $20 \%$ of people in this role have a Bachelor's Degree today. Potential transitions from this origin occupation based on our skill distance score cutoff would be to the following destination occupations: Market Research Analysts and Marketing Specialists, Computer Occupations, Drafters, Compensation, Benefits, and Job Analysis Specialists and Financial Analysts. In California, these destination jobs all pay higher wages than the Statistical Assistant job. The second example illustrates potential transitions for a Childcare worker in New York. The average income for a Childcare worker is $\$ 10.29 / \mathrm{hr}$. in that state. This individual's most important skills include Monitoring, Service Orientation and Social Perceptiveness. Potential destination occupations we find for this worker based on our criteria include Customer Service Representatives, Athletes, Coaches, Umpires, Teachers and Instructors, Cargo and Freight Agents and Bartenders. Each of these destination jobs pay wages that are two to four times the average wages of a childcare worker.

\begin{tabular}{|c|c|c|c|c|c|c|c|c|}
\hline \multicolumn{4}{|c|}{ Origin Occupation } & \multicolumn{4}{|c|}{ Destination Occupation } & \multirow[b]{2}{*}{ Skill Distance } \\
\hline $\begin{array}{l}\text { Occ } \\
\text { Code }\end{array}$ & Title & $\begin{array}{l}\text { Wage } \\
(\$ / h r .)\end{array}$ & $\begin{array}{c}\text { BA Share } \\
(\%)\end{array}$ & $\begin{array}{l}\text { Occ. } \\
\text { Code }\end{array}$ & Title & $\begin{array}{l}\text { Wage } \\
(\$ / h r .)\end{array}$ & $\begin{array}{l}\text { BA Share } \\
(\%)\end{array}$ & \\
\hline \multicolumn{9}{|c|}{$\underline{\text { State: California }}$} \\
\hline 5920 & Statistical Assistants & 17.61 & 0.19 & 735 & $\begin{array}{l}\text { Market Research Analysts \& } \\
\text { Specialists }\end{array}$ & 53.1 & 0.82 & 2.11 \\
\hline 5920 & Statistical Assistants & 17.61 & 0.19 & 1107 & Computer Occupations, Other & 45.65 & 0.59 & 2.13 \\
\hline 5920 & Statistical Assistants & 17.61 & 0.19 & 1540 & Drafters & 49.77 & 0.3 & 2.34 \\
\hline 5920 & Statistical Assistants & 17.61 & 0.19 & 640 & $\begin{array}{l}\text { Compensation, Benefits, \& Job } \\
\text { Analysis Specialists }\end{array}$ & 24.3 & 0.61 & 2.43 \\
\hline 5920 & Statistical Assistants & 17.61 & 0.19 & 840 & Financial Analysts & 73.4 & 0.89 & 2.46 \\
\hline \multicolumn{9}{|c|}{$\underline{\text { State: New York }}$} \\
\hline 4600 & Childcare Workers & 10.29 & 0.15 & 5240 & $\begin{array}{l}\text { Customer Service } \\
\text { Representatives }\end{array}$ & 30.53 & 0.26 & 1.68 \\
\hline 4600 & Childcare Workers & 10.29 & 0.15 & 2720 & $\begin{array}{l}\text { Athletes, Coaches, Umpires, and } \\
\text { Related Workers }\end{array}$ & 31.62 & 0.48 & 1.77 \\
\hline 4600 & Childcare Workers & 10.29 & 0.15 & 2340 & Teachers \& Instructors & 26.98 & 0.55 & 1.90 \\
\hline 4600 & Childcare Workers & 10.29 & 0.15 & 5500 & Cargo \& Freight Agents & 42.86 & 0.15 & 1.93 \\
\hline 4600 & Childcare Workers & 10.29 & 0.15 & 4040 & Bartenders & 38.13 & 0.27 & 2.00 \\
\hline
\end{tabular}

Table 3. Example of Predicted Transitions using STARs Framework 


\section{Defining STARs}

Equipped with the income groups definition and the potential transitions, we could quantify the workers in the target study population who have transitions available to destination occupations with higher wages. A meaningful way to segment this group of workers is by their skills-readiness for higher-wage work as measured by their experience similarity scores to destination occupations. We thus segment the 68 million STARs into the four categories below based on a worker's ability to transition to higher wages based on their skills. The definition of each segment is in Table 4:

\begin{tabular}{|c|c|c|}
\hline $\begin{array}{l}\text { STAR } \\
\text { SEGMIENT }\end{array}$ & $\begin{array}{l}\text { CONCEPTUAL } \\
\text { DEFINITION }\end{array}$ & $\begin{array}{l}\text { QUANTITATIVE } \\
\text { OPERATIONALIZATION }\end{array}$ \\
\hline SHINING & $\begin{array}{l}\text { Workers without a four- } \\
\text { year degree who are in } \\
\text { high-wage roles today }\end{array}$ & $\begin{array}{l}\text { Target Study Population (TSP) } \\
\text { already working in high- } \\
\text { wage occupations (above two } \\
\text { median wages). }\end{array}$ \\
\hline RISING & $\begin{array}{l}\text { Workers without a four- } \\
\text { year degree who have } \\
\text { skillsets to transition to } \\
\text { high or middle-wage } \\
\text { work }\end{array}$ & $\begin{array}{l}\text { TSP with high or middle- } \\
\text { wages after transitions. } \\
\text { They are currently in low or } \\
\text { middle income occupations, } \\
\text { but have skills similar to the } \\
\text { ones required by high income } \\
\text { roles }\end{array}$ \\
\hline $\begin{array}{l}\text { FORMING } \\
\text { STARS }\end{array}$ & $\begin{array}{l}\text { Workers without a four- } \\
\text { year degree in low or } \\
\text { middle-wage roles who } \\
\text { have skills to transition } \\
\text { to a higher wage role in } \\
\text { their wage category, but } \\
\text { not to transition to the } \\
\text { next wage group. }\end{array}$ & $\begin{array}{l}\text { TSP in low or middle income } \\
\text { roles who do not have skills to } \\
\text { transition to the next income } \\
\text { threshold but who do have } \\
\text { skills to transition to a higher } \\
\text { wage. }\end{array}$ \\
\hline
\end{tabular}

Table 4. Definitions of STAR Segments 


\begin{tabular}{|l|l|l|l|}
\hline WAGE SEGMENT & $\begin{array}{l}\text { Low-wage } \\
\text { Destination Job: }\end{array}$ & $\begin{array}{l}\text { Middle-wage } \\
\text { Destination Job: }\end{array}$ & $\begin{array}{l}\text { High-wage } \\
\text { Destination Job: }\end{array}$ \\
\hline $\begin{array}{l}\text { Low-wage } \\
\text { Origin Job: }\end{array}$ & $\begin{array}{c}\text { Forming STARs } \\
(\mathbf{1 3 . 8} \text { million) }\end{array}$ & $\begin{array}{c}\text { Rising STARs } \\
(\mathbf{1 8 . 8} \text { million })\end{array}$ & $\begin{array}{c}\text { Rising STARs } \\
(\mathbf{1 . 4} \text { million })\end{array}$ \\
\hline $\begin{array}{l}\text { Middle-wage } \\
\text { Origin Job: }\end{array}$ & & $\begin{array}{c}\text { Forming STARs } \\
(\mathbf{1 9 . 1} \text { million })\end{array}$ & $\begin{array}{c}\text { Rising STARs } \\
(\mathbf{9 . 8} \text { million })\end{array}$ \\
\hline $\begin{array}{l}\text { High-wage } \\
\text { Origin Job: }\end{array}$ & & & $\begin{array}{c}\text { Shining STARs } \\
(\mathbf{5 . 2} \text { million })\end{array}$ \\
\hline
\end{tabular}

Table 5. Counts by STARs Taxonomy

Table 5 above illustrates the potential transitions from origin to destination jobs based on the experience similarity measure for STARs. Of the 34 million STARs in low-wage positions, 13.8 million do not have transition opportunities that move them outside the low-wage income group. We call them Forming STARs. There are 18.8 million low-wage workers who have skills to transition to middle-wage jobs, and 1.4 million who have the skills to transition to high-wage jobs. We call these combined 20.2 million workers Rising STARs. There are 28.9 million STARs in middle-wage jobs. Of these STARs, 19.1 million do not have skills to transition out of their wage category. As such, we refer to this group as Forming STARs as well. The STARs in middlewage jobs who could transition to the high-wage group include 9.8 million STARs who are also Rising STARs. Finally, we find 5.2 million are Shining STARs: these are workers earning a highwage today.

\section{$\underline{\text { Results/Description of Findings }}$}

There is meaningful variation across this segmentation, which we describe in this section. The calculations we display in Figure 7 show the average distance of the importance of skills across all low- and middle-wage jobs. Low-wage jobs have higher levels of import of the skills seen in the upper left part of the circle in Figure 7 and middle-wage jobs have a higher level of import of skills on the upper right part of the circle. Studying the average differences in importance of each skill, we find that low-wage jobs, on average, have higher import levels of Service Orientation, Operations and Control, Troubleshooting, Social Perceptiveness and Monitoring. The skills for which low-wage jobs have gaps compared to middle-wage jobs are in skills that tend to be more technical in nature: Operations Analysis, Science, Systems Analysis, Systems Evaluation, Management of Financial Resources, Management of Personnel Resources, and Programming. 


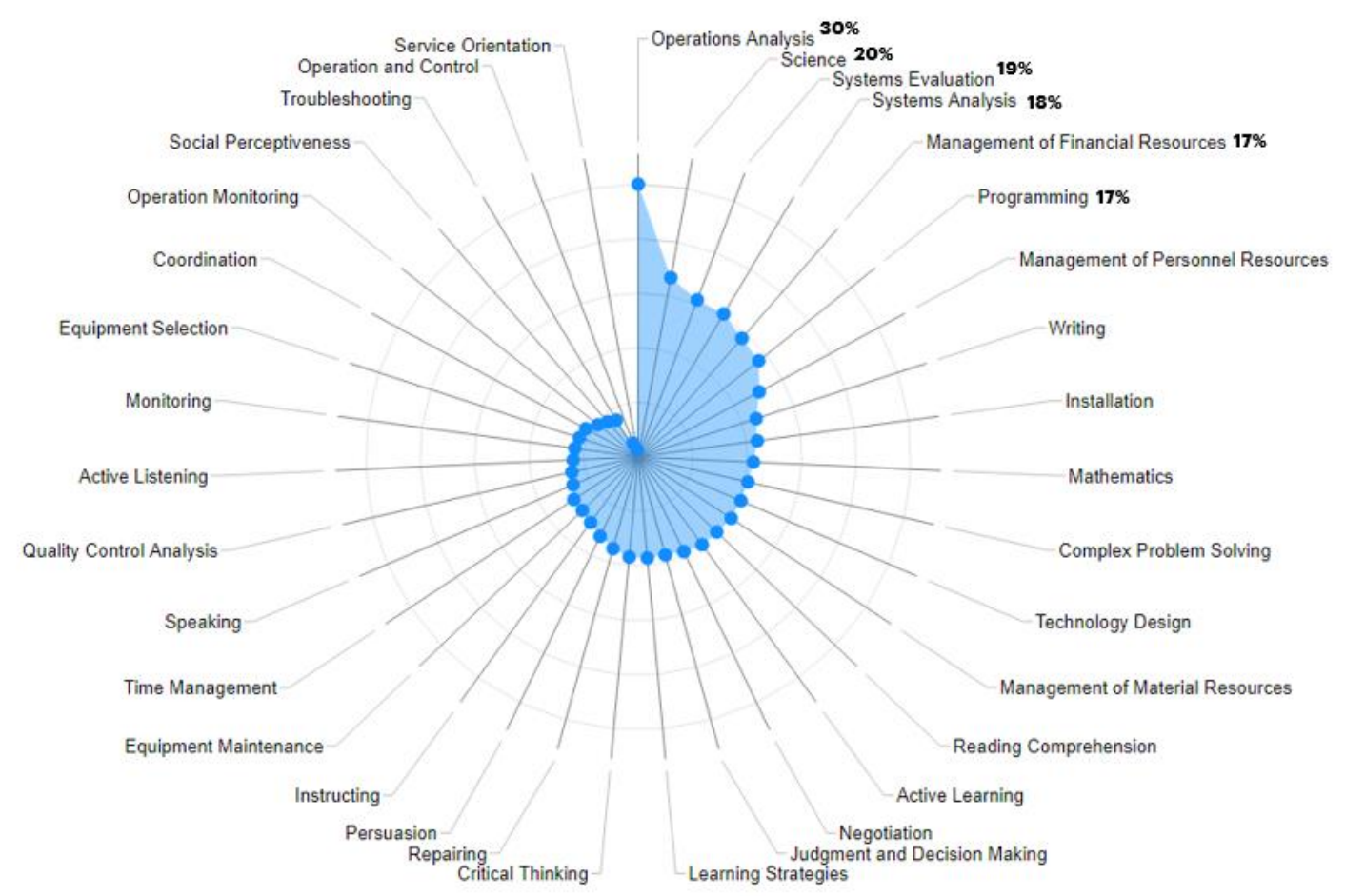

Figure 7. Differences in Skill Importance Across Low and Middle-wage Occupations

The differences in importance of skills across two occupations is one component of the skill distance between two occupations. We use the skill distance to understand if a STAR has the skills to earn higher wages based on the skill content of their current job and how proximate it is to a higher earning, potential destination job. The transitions we predict from each STAR's origin job to his destination job is defined by the skill distance score and other parameters we define in the Methods section. These transitions are illustrated at the 2-digit SOC code level in Figure $8 .^{18}$ The Y-axis of Figure 8 represents the origin major job group for each STAR, and the Y-axis represents the destination occupation for each STAR.

The transitions of workers starting at the higher end of the wage distribution on the Y-axis are to other roles within the same major job group. This is expected: the skills required in occupations that belong to the major job group frequently share the same area of knowledge and require the worker to perform similar tasks. We do find opportunities to transition to other major job groups, especially at the lower end of the wage distribution on the Y-axis. The data supports the finding that the skills developed on the job by these workers are compatible with requirements of higher paid jobs. For instance, for approximately $40 \%$ of occupations in the Personal Care and Service major occupation group - the job group with the lowest national median income - the predicted transitions based on the skill distance score are to other roles within that major job group. However, some roles within that major job group have greater upward mobility: $20 \%$ of the transitions we predict for workers in roles in the Personal Care and Service major job group are to jobs in the Educational Instruction major job group or Office and Administrative support major

\footnotetext{
${ }^{18}$ The Bureau of Labor Statistics classifies all workers into the Standard Occupational Classification (SOC) system, which is used by all federal agencies. The SOC includes 867 detailed occupations, which can be combined into 459 broad occupations, 98 minor groups, or 23 major ("2-digit") groups. For more information, see https://www.bls.gov/soc/. We illustrate the 23 major job groups in this chart.
} 
job group. Both of these job groups have a higher average median wage than the Personal Care and Service major job group.

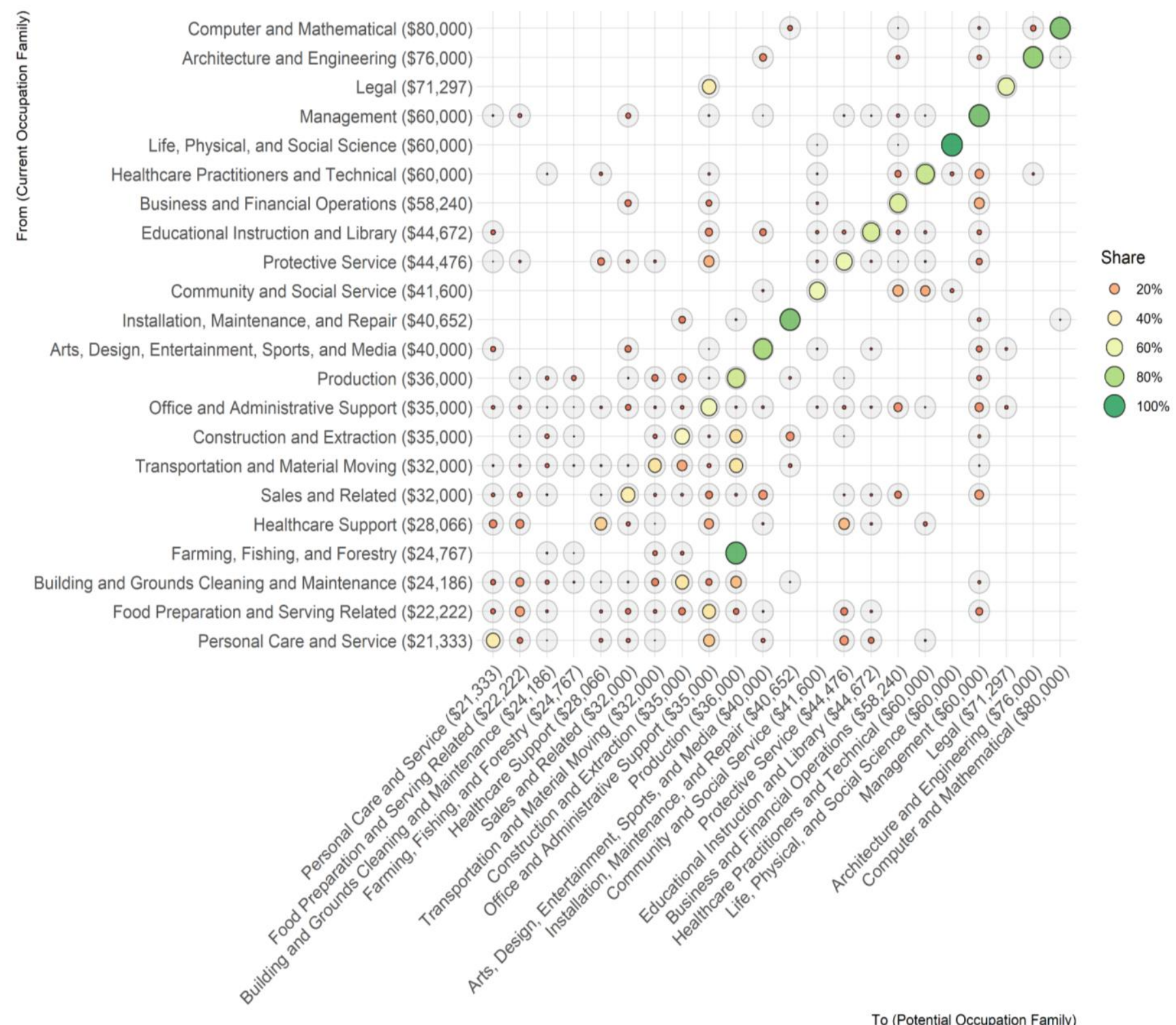

Figure 8. Predicted Transitions for STARs based on skill distance score

Other predicted transitions move STARs out of their major job group: for instance, many roles within the Farming, Fishing and Forestry major job group have many skills similar to the skills required of roles within the Production major job group. Another notable major job group on this chart is the Sales and Related group: our approach suggests potential transitions for workers from origin jobs in this category to destination jobs in the Office and Administrative Support group, the Arts, Designs, Entertainment and Media group and Business and Financial Operations 
group. Most of these transitions - which are outside the immediate major job group - are to higherwage positions for the worker.

STARs' transition opportunities vary based on their skills, which we illustrate through a segmentation based on STARs' skills-readiness for higher wage work. We present the distribution of the 68 million STARs across 3 main segments in Figure 9. There are 5.2 million STARs in highwage roles today, STARs we call Shining STARs. As displayed in Figure 10 below, Shining STARs are most commonly in roles in the Computer and Mathematics, and Management job groups.

Rising STARs are STARs who have skill distance scores from their origin occupation to a destination occupation that could move them to (at least)the next wage group. ${ }^{19}$ As we show in Figure 9, there are 30 million Rising STARs, 9.8 million of which are middle-wage roles, and 20.2 million of which are in low-wage roles. Figure 10 shows the most common job groups for middlewage Rising STARs include Sales, Management and Office Administrative occupations; for lowwage Rising STARs, the most common job groups are in Office Administration, Transportation and Sales occupations.

- TSP Age 25+

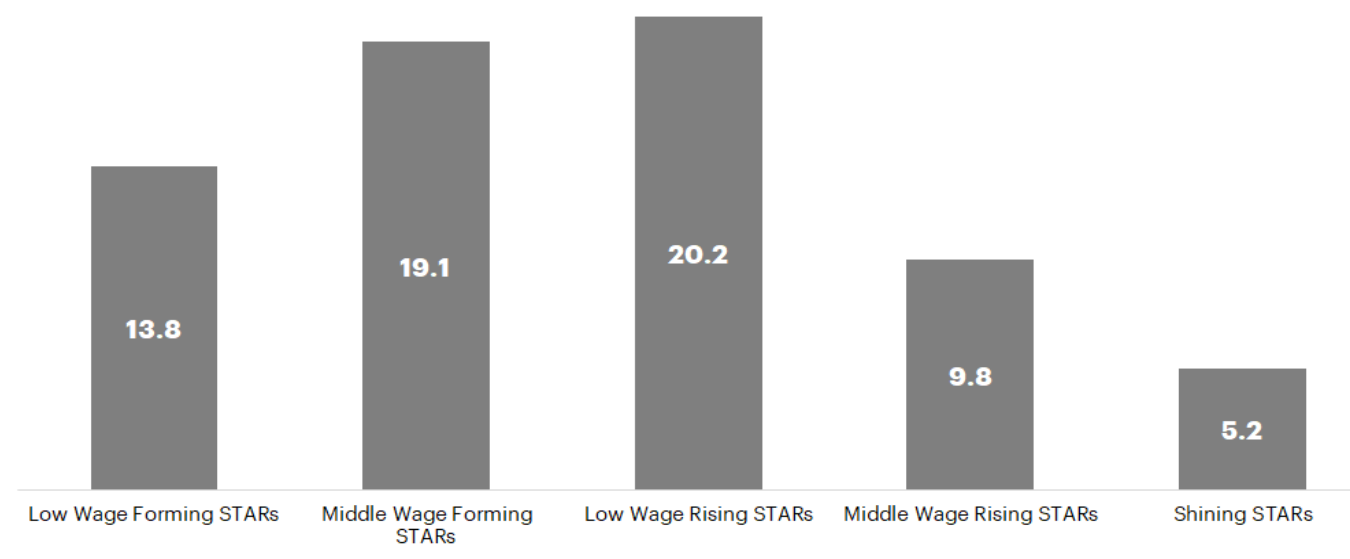

Figure 9. Distribution of STARs by Segment

Finally, there are 32.9 million Forming STARs, currently in middle-wage and low-wage roles. While these workers have skills to transition to higher wages - each could experience at least a $10 \%$ increase in wages based on this predicted transition - they will not experience wage gains to the next wage category based on their current skills. There are 13.8 million low-wage Forming STARs, 19.1 million middle-wage Forming STARs. Figure 10 shows the most common job groups for middle-wage Forming STARs include Personal Care and Office Administrative occupations; for low-wage Forming STARs, the most common job groups are in Office Administration and Production occupations.

In Figure 10, we illustrate the distribution of STARs current occupations by segment. The $\mathrm{X}$-axis details the major job group and median wages (at the 2-digit SOC level) ranging from the lowest-wage major job group of Personal Care (median wage of $\$ 10 / \mathrm{hr}$.) to the highest-wage major job group of Computer and Mathematics (median wage of $\$ 35 / \mathrm{hr}$.). The Y-axis illustrates the STAR segment. Each green circle illustrates the proportion of STARs in that major job group. For

\footnotetext{
${ }^{19}$ We predict transitions for 1.4 million STARs from the low-wage to high-wage category..
} 
instance, as illustrated by the green circles on the bottom left, we see a higher proportion of lowwage STARs - across both the Forming and Rising categories - in the lower-wage occupations of Personal Care and Services, Food Preparation and Building and Grounds Cleaning. And as illustrated by the green circles at the top right of the chart, we observe a higher proportion of Shining STARs in roles that are higher wage, such as Computer and Mathematical and Management job groups.

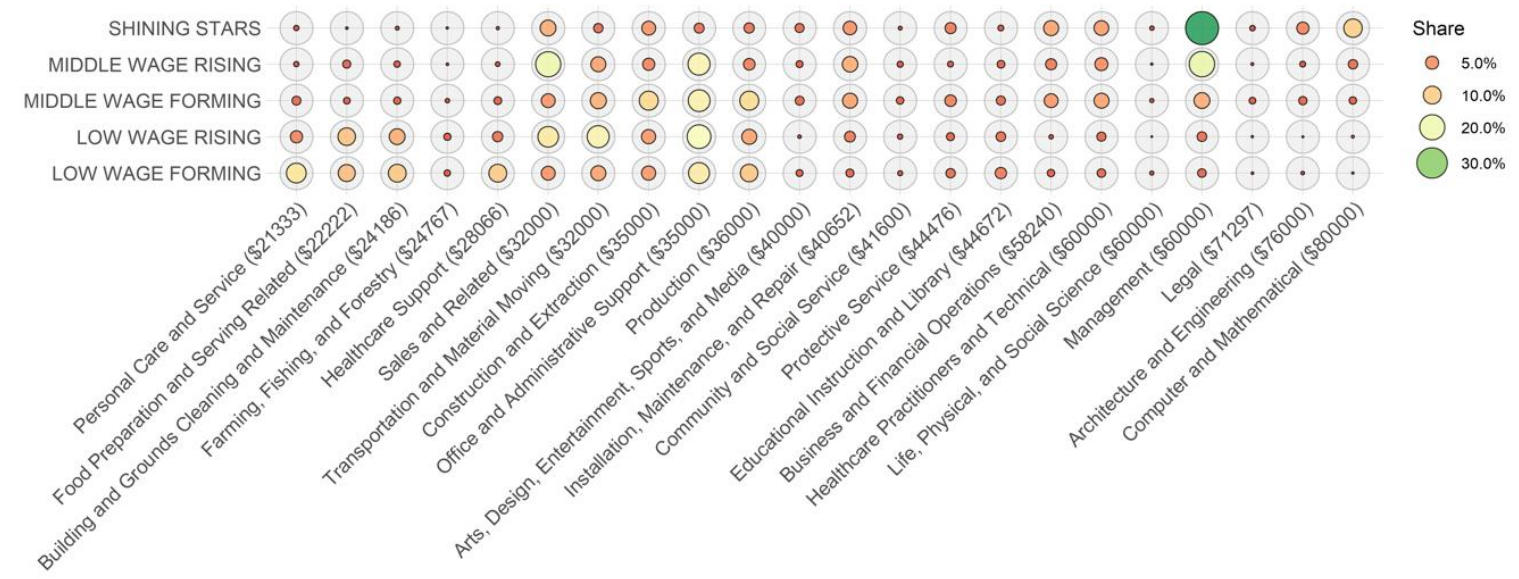

Figure 10. Predicted Transitions for STAR Segments Within and Across Job Groups

The data illustrates that STARs are in almost all job groups, but that STARs occupy a higher proportion of some job groups than others. Further, there is a high volume of STARs across the STARs segment spectrum in the Office and Administrative Support major job group.

We detail the Potential Wage increases in Figure 11. Potential wage increases that result from these predicted transitions vary across segments. First, all STARs have transition opportunities to roles that pay $10 \%$ more in wages in their state. For Forming STARs, many transition opportunities do not lead to significant wage gains. For instance, while a taxi driver in our analysis could transition to a truck driver, that destination occupation pays little more than $10 \%$ more of his current wages. For Rising STARs, transition opportunities are significantly higher: the potential average increase in wages is almost $75 \%$.

Predicted Increase in Wages Post-Transition

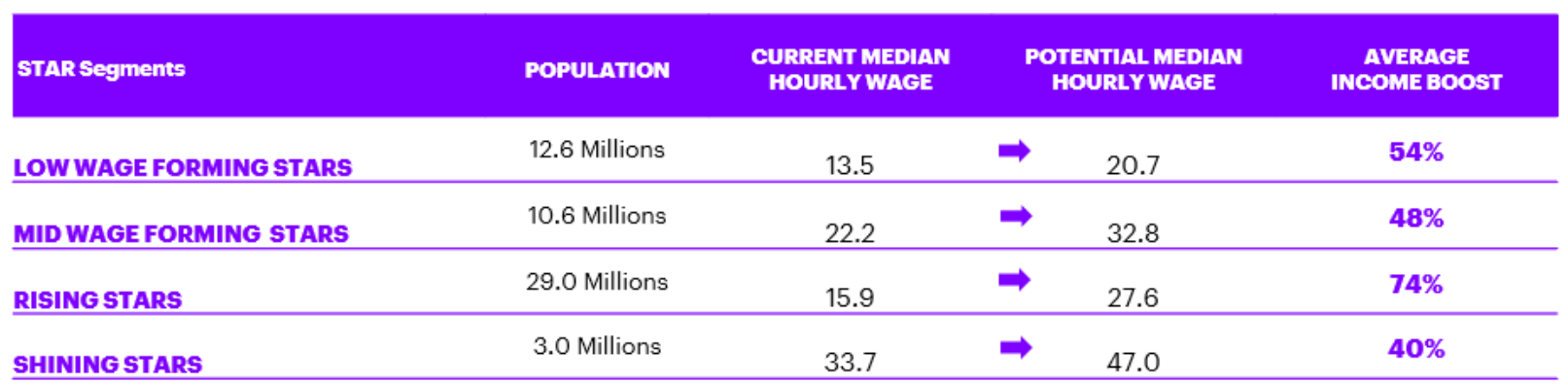

Figure 11. Predicted Increase in Wages Post-Transition 
There is meaningful variation in the age, gender, race and ethnicity and educational attainment across the STARs segments, as shown in Figure 12. Though we calculated median wages by state and age group when estimating wages for STARs and find important differences across the groups. Shining STARs, those in high-wage jobs, are older than low-wage STARs (both Forming and Rising). Whereas $70 \%$ of Shining STARs are over the age of 45 , more than $50 \%$ of low-wage STARs are between the ages of 25-44. Almost $70 \%$ of Shining STARs, and almost $60 \%$ of middle-wage workers - in both the Rising and Forming segments - are men. However, looking at the low-wage workers, the distribution across gender is closer to an even split, with women comprising $56 \%$ of low-wage Forming STARs. It is important to recognize social, historical and market factors that drive pay bands for some professions. For instance, the major job groups that pay less also have a higher proportion of women than men, and even within that major job group, occupations pay different wages to men than women. For instance, the median earnings of janitors (usually men) is $22 \%$ higher than maids and house cleaners (usually women). ${ }^{20},{ }^{21}$

There are differences in the racial and ethnic diversity across these segments as well. Whereas more than three-quarters of Shining STARs are white, less than $60 \%$ of low-wage Forming and Rising STARs are white. Within the Forming STAR category, 20\% of workers are non-white Hispanic, and almost $16 \%$ are black. Finally, the educational attainment of workers varies across these groups. Whereas $2 / 3$ of Shining STARs have some college or an associate's degree, fewer than half of low-wage STARs have an educational attainment beyond high school.

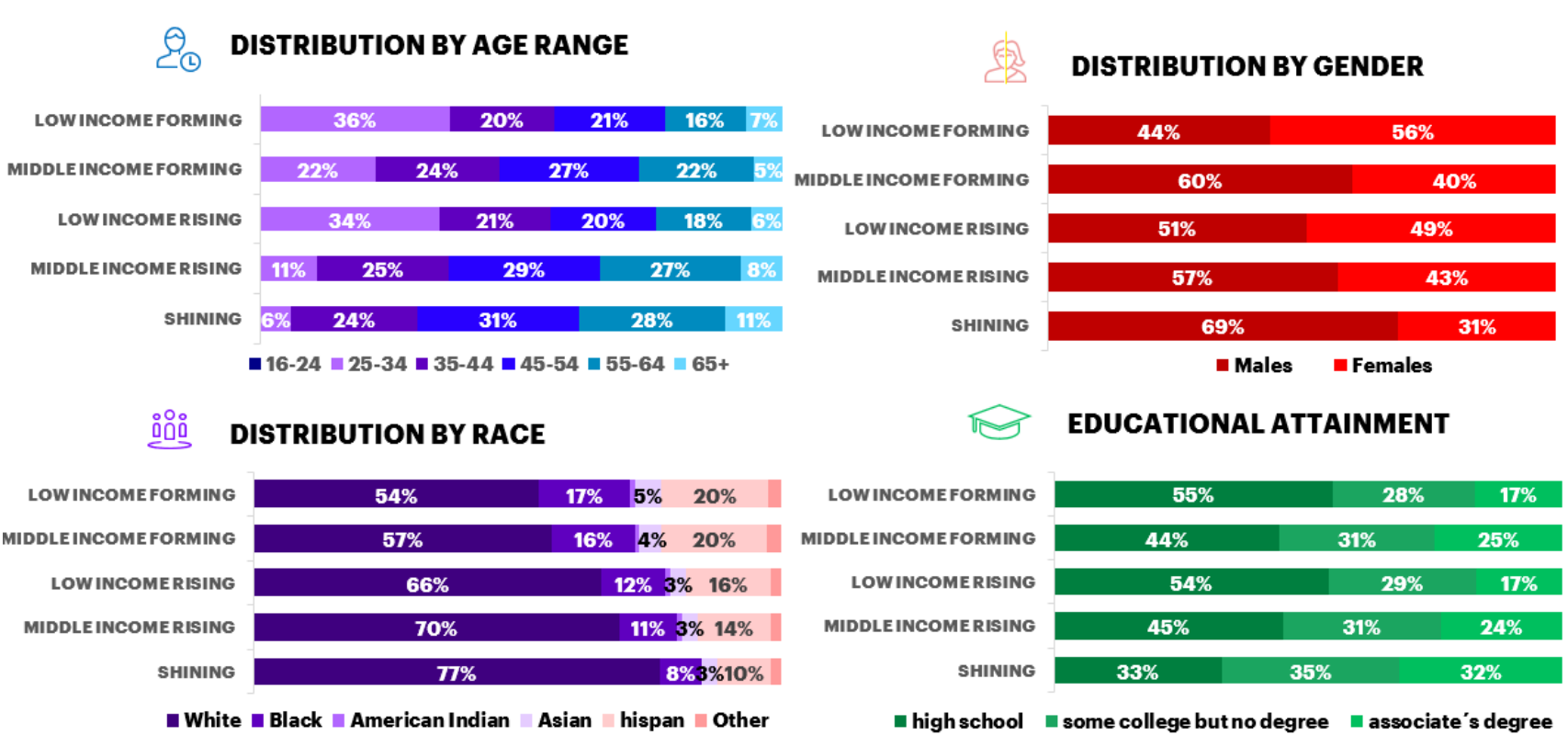

Figure 12. Demographics of STARs by Segment

\footnotetext{
${ }^{20}$ Levanon, Asaf, “Occupational Feminization and Pay: Assessing Causal Dynamics Using 1950-2000 U.S. Census Data” December 2009 https://academic.oup.com/sf/article-abstract/88/2/865/2235342

${ }^{21}$ Miller, Claire Cain. “As Women Take Over a Male Dominated Field, The Pay Drops. ” March 2016 https://www.nytimes.com/2016/03/20/upshot/as-women-take-over-a-male-dominated-field-the-pay-drops.html
} 
Figure 13 illustrates the proportion of STARs to the active working population in each state: yellow indicates that STARs make up a higher proportion of working adults, while purple indicates they represent a smaller proportion of working adults. The data shows that STARs make up $50 \%$ or less of the active working population in DC, as well as Colorado, California and several other states on the east coast: Massachusetts, New Jersey, Maryland, New York, Connecticut and Virginia. They make up more than $65 \%$ of the active working populations in Mississippi, West Virginia and Wyoming.

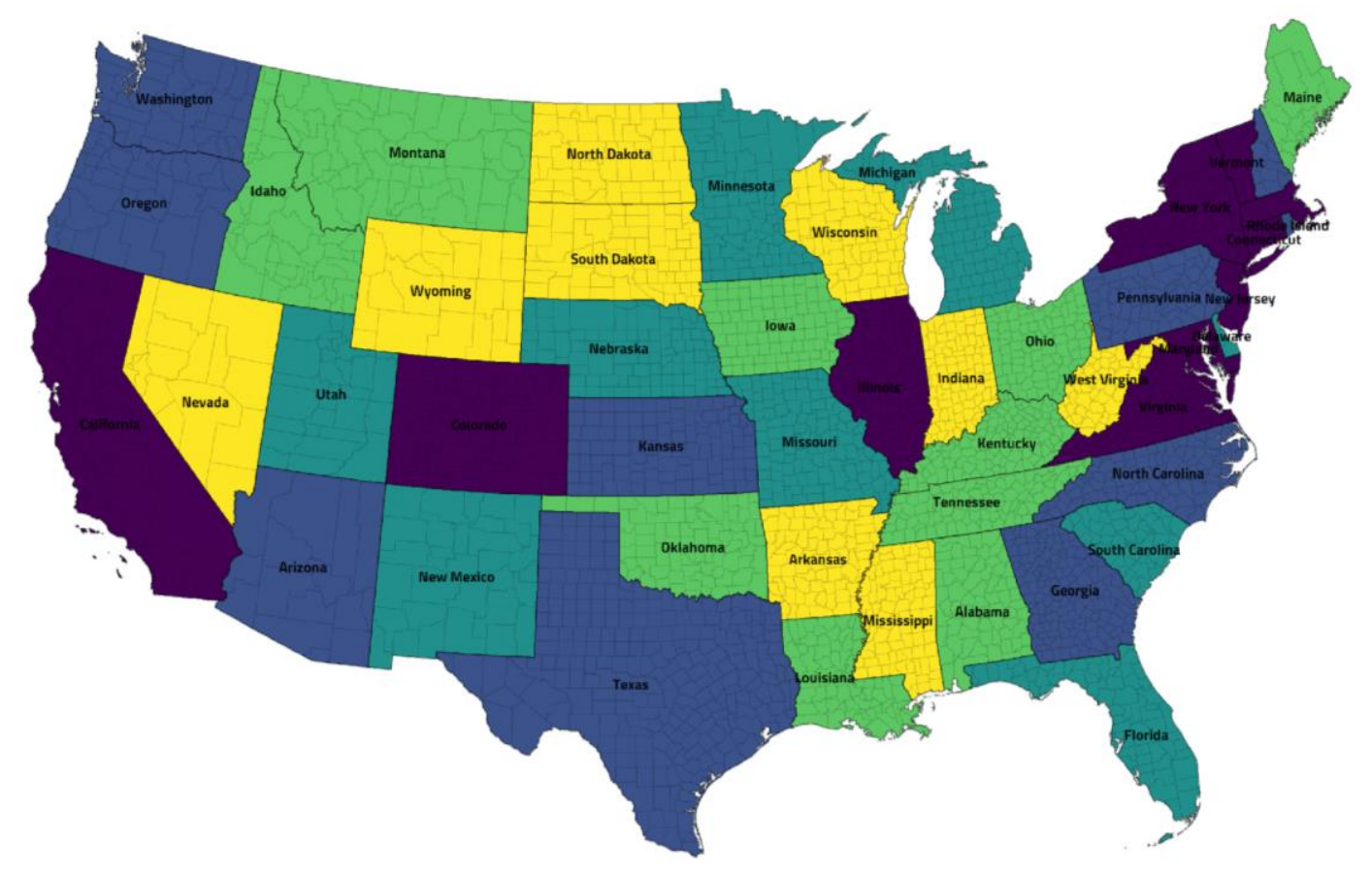

TSP Share (\%)
\begin{tabular}{|}
$62-68 \%$ \\
$59-61 \%$ \\
\hline $56-58 \%$ \\
\hline $52-55 \%$ \\
\hline $29-51 \%$ \\
\hline
\end{tabular}

Figure 13. Geographic Distribution of STARs 


\section{Conclusion}

For markets to work well, participants need good information. In the absence of perfect information, signals provide an important second best solution for achieving market efficiency. Workers with college degrees possess a well-established labor market signal that cuts across industries, while workers without college degrees generally do not. Moreover, skills developed through work experience can be difficult for employers to assess, particularly when they are acquired in seemingly unrelated occupations and are high-dimensional in nature.

To study the market for skills faced by workers without BA degrees, we borrow a key insight from the International Trade and IO literature: distances matter for describing the shape of economic activity. Using a readily available dataset on the skill requirements of occupations (O*NET), we construct the Euclidean distance between the skill content of a worker's origin job and the skill content of all other destination jobs in the dataset. To identify potential pathways to higher wage destination jobs, we search for destination jobs that: 1) are close in the skill space to the origin job; 2) currently employ some workers without BA degrees; 3) in the recent past have hired workers from the origin job who did not possess a BA degree; and, 4) pay higher average state-cohort median wages than the origin job.

To characterize these potentially plausible transitions we develop a taxonomy the STARs, i.e. workers without BA degrees who based on the skill content of their current occupations are

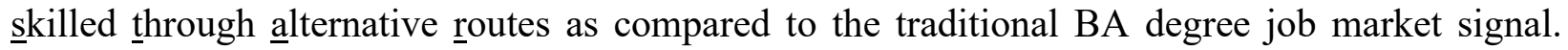
Based on our measure of plausible job transitions, of the 68 million workers without BA degrees in the US, 30 million are "Rising STARs" whose skills are compatible with working in destination jobs with average earnings that are higher by $\$ 11$ hour. Another 33 million are Forming STARs whose skills are compatible with working in destination jobs with average earnings that are higher by $\$ 7 \backslash$ hour. The presence of 5 million "Shining STARs," who are workers without BA degrees earning greater than twice the median state-cohort wage (in their current/origin jobs) is consistent with the proposition that high wage work exists for workers without BA degrees. These findings suggest that there is a potentially vast pool of skilled labor for US employers.

One potential concern of opening career paths to more STARs is that it could crowd out workers with college degrees. While we do not have a direct measure of crowd out in our paper, recent hiring and job posting patterns suggest very strong demand for more skilled workers. This demand in fact exceeds both the stock and flow of college-educated labor. The open question is how do we define who is a skilled worker? And whether skills learned through proximate work experience figures into the definition of who is a skilled worker? To the extent that it does, measuring skills using current work experience opens the door to workers without BA degrees having access to a labor market signal. The skill distance measure that we propose is one way to do this. To the extent our proposed categories are accurate, working with skill-matched STARs offers employers an accessible and immediate means to address some of their needs for skilled workers. In turn, firms filling more high-wage jobs with experienced non-BA workers has the potential to reshape the historic pattern of earnings inequality between workers with and without college degrees. 


\section{$\underline{\text { References }}$}

Altonji, Joseph G., and Charles R. Pierret. 2001. "Employer Learning and Statistical Discrimination." The Quarterly Journal of Economics 116 (1): 313-50.

Arrow, Kenneth J. 1986. "Rationality of Self and Others in an Economic System." The Journal of Business 59 (4): S385-99.

Autor, David. 2019. "Work of the Past, Work of the Future." AEA Papers and Proceedings 109: $1-32$.

Autor, David H. 2014. "Skills, Education, and the Rise of Earnings Inequality among the 'Other 99 Percent." Science 344 (6186): 843-51.

Autor, David H., Claudia Dale Goldin, and Lawrence F. Katz. 2020. "Extending the Race Between Education and Technology."

Autor, David H., Lawrence F. Katz, and Melissa S. Kearney. 2006. "The Polarization of the U.S. Labor Market." American Economic Review 96 (2): 189-94.

- 2008. "Trends in U.S. Wage Inequality: Revising the Revisionists." The Review of Economics and Statistics 90 (2): 300-323.

Bergstrand, Jeffrey H. 1985. "The Gravity Equation in International Trade: Some Microeconomic Foundations and Empirical Evidence." The Review of Economics and Statistics 67 (3): 474-81.

Blair, Peter Q., and David J. Deming. 2020. "Structural Increases in Demand for Skill after the Great Recession.” American Economic Review 110 (1-5): 496-501.

Bureau of Labor Statistics, U.S. Department of Labor, Employment Projections, Table 1.7 Occupational projections, 2018-28, and worker characteristics, 2018, https://data.bls.gov/projections/occupationProj (visited February 21, 2020).

Bureau of Labor Statistics, U.S. Department of Labor, Employment Projections, Table 5.3 Educational attainment for workers 25 years and older by detailed occupation, 2016-17, https://data.bls.gov/projections/occupationProj (visited February 21, 2020).

Bureau of Labor Statistics, U.S. Department of Labor, The Economics Daily, Occupations typically requiring high school for entry lost 1.3 million jobs, May 2007-16 on the Internet at https://www.bls.gov/opub/ted/2017/occupations-typically-requiring-high-school-for-entry-lost-13-million-jobs-may-2007-16.htm (visited February 21, 2020). 
Caplin, Andrew, and Mark Dean. 2015. "Revealed Preference, Rational Inattention, and Costly Information Acquisition.” American Economic Review 105 (7): 2183-2203.

Coate, Stephen, and Glenn C. Loury. 1993. "Will Affirmative-Action Policies Eliminate Negative Stereotypes?" The American Economic Review 83 (5): 1220-40.

Donaldson, Dave. 2018. "Railroads of the Raj: Estimating the Impact of Transportation Infrastructure." American Economic Review 108 (4-5): 899-934.

Gabaix, Xavier. 2014. “A Sparsity-Based Model of Bounded Rationality." The Quarterly Journal of Economics 129 (4): 1661-1710.

Gandhi, Amit, and Jean-Francois Houde. n.d. "Measuring Substitution Patterns in Differentiated Product Industries."

Goos, Maarten, and Alan Manning. 2007. "Lousy and Lovely Jobs: The Rising Polarization of Work in Britain." The Review of Economics and Statistics 89 (1): 118-33.

Goos, Maarten, Alan Manning, and Anna Salomons. 2014. "Explaining Job Polarization: RoutineBiased Technological Change and Offshoring." American Economic Review 104 (8): 2509-26.

Groshen, Erica L. and Harry J. Holzer. 2019a. "Improving Employment and Earnings in TwentyFirst Century Labor Markets: An Introduction," RSF: The Russell Sage Foundation Journal of the Social Sciences December 2019, 5 (5); DOI: https://doi.org/10.7758/RSF.2019.5.5.

Groshen, Erica L. and Harry J. Holzer 2019b. eds. "Improving Employment and Earnings in Twenty-First Century Labor Markets," RSF: The Russell Sage Foundation Journal of the Social Sciences December 2019, 5 (5); DOI: https://www.rsfjournal.org/content/5/5

Katz, Lawrence F., and Kevin M. Murphy. 1992. "Changes in Relative Wages, 1963-1987: Supply and Demand Factors." The Quarterly Journal of Economics 107 (1): 35-78.

Laibson, David. 1997. "Golden Eggs and Hyperbolic Discounting." The Quarterly Journal of Economics 112 (2): 443-78.

Matějka, Filip, and Alisdair McKay. 2015. "Rational Inattention to Discrete Choices: A New Foundation for the Multinomial Logit Model.” American Economic Review 105 (1): 272-98.

Pallais, Amanda. 2014. "Inefficient Hiring in Entry-Level Labor Markets." American Economic Review 104 (11): 3565-99.

Pallais, Amanda, and Emily Glassberg Sands. 2016. "Why the Referential Treatment? Evidence from Field Experiments on Referrals.” Journal of Political Economy 124 (6): 1793-1828. 
Sims, Christopher A. 2003. "Implications of Rational Inattention." Journal of Monetary Economics, Swiss National Bank/Study Center Gerzensee Conference on Monetary Policy under Incomplete Information, 50 (3): 665-90.

Spence, Michael. 1973. “Job Market Signaling.” The Quarterly Journal of Economics 87 (3): $355-$ 74.

Tinbergen, Jan. 1974. "Substitution of Graduate by Other Labour*." Kyklos 27 (2): 217-26.

U.S. Census Bureau, Current Population Survey, Annual Social and Economic Supplement, 2018. https://www.census.gov/cps/data/cpstablecreator.html (visited February 28, 2020). 